UDC 531.66

\title{
MODEL OF HIGH-SPEED SHOCK INTERACTION WITH COMPATIBLE TYPE
}

\author{
A.V. Kovtun, \\ Candidate of Technical Science, Associate Professor ${ }^{1}$ \\ V.O. Tabunenko, \\ Candidate of Technical Science, Associate Professor ${ }^{2}$ \\ S.I. Nesterenko, \\ Candidate of Technical Science, Associate Professor ${ }^{3}$ \\ ${ }^{1}$ National Academy of the National Guard of Ukraine, Kharkiv, Square Zakhysnykiv Ukrayiny3, \\ Kharkiv, 61001 \\ ${ }^{2}$ National Air Force UniversityIvan Kozhedub, Kharkiv, Sumska Street 77/79, Kharkiv, 61023 \\ ${ }^{3}$ National Aerospace University - Kharkiv Aviation Institute, Kharkiv, Chkalova Street 17, \\ Kharkiv, 61070
}

DOI: $10.32347 / 2410-2547.2020 .105 .64-72$

This research aims to the process of interaction of a bullet (fragment) with protective barriers, which are formed by a set of hollow cylinders of a compatible type. Models for determining the depth of penetration of the drummer into an obstacle in the form of a set of hollow cylinders of compatible type are proposed. The results of calculations of the value of the depth of penetration of the bullet into the protective barrier in the form of a set of compatible cylinders. Further research is related to the improvement of the armor protection designs by developing new technical solutions using the latest technologies.

Keywords: model, compatible cylinders, high-speed drummer, bullet, protective obstacle, deformation, hollow cylinder.

Formulation of the problem. In connection with the ongoing hostilities in eastern Ukraine, the issue of developing the protection of servicemen from bullets and shrapnel remains relevant. Modern research on the interaction of bullets and fragments with protective barriers is based on the search for new types of structures and protective materials. The main focus is on the development of protective structures that would increase the level of protection of servicemen, according to NATO standards, using inexpensive available materials with minimal costs for their production and intended use.

Despite some progress in the investigation of collisions of solids, the known results of theoretical and experimental research do not describe a holistic picture of the interaction of the element of damage and interference. Therefore, in the development of protective structures take into account only certain aspects of impact interaction, which are based on the absorption of kinetic energy of the element of damage [1].

The scientific and technical task remains important study of the process of interaction of bullets (fragments) with protective barriers, at the stages of penetration, breaking and their departure, which will develop new models of 
protection design for servicemen, which are relevant for the Armed Forces of Ukraine.

Analysis of recent research and publications. The issues of interaction of bullets (fragments) with protective obstacles have long been dealt with and various methods and approaches to calculating the depth of penetration of obstacles have been known. Fundamental results of the study of the phenomenon of impact and determination of the conditions for breaking through obstacles by drummers (bullets, fragments) were obtained in the works of Euler, Jacob de Mar, Noble, J. Reinhart and J. Pearson, Berzin K.A. and others [1].

In modern research, methods and ways to increase the security of personnel of military bases and units, combat vehicles and fortifications are given considerable attention [1-7].

In [1] the parameters of the multilayer protective structure of combat vehicles based on nonlinear mathematical models are substantiated. In [2] the method of research of complex systems of military purpose is resulted. In [3-6] the modeling of the dynamics of the reaction of the protective structure to the action of the shock-wave load at the impact of a bullet or a fragment of a projectile is considered. In [7] materials for local and individual armoring are investigated. A study of the use of non-traditional methods of interaction of bullets (fragments) with protective barriers is given in research [8].

The main method of studying the process of impact and punching an obstacle with a bullet (fragment) is a combination of analytical and experimental researches. Analytical research methods are based on mathematical modeling of the stages of interaction of bullets (fragments) with the elements of the protective barrier, followed by appropriate mathematical calculations [1]. Experimental research methods are based on determining the level of protection of protected objects and require complex research in laboratory and landfill conditions. The combination of the results of analytical and experimental research allows us to more fully consider the level of protection of protected objects.

However, studies of the interaction of bullets (fragments) with protective obstacles have not been completed, the processes occurring when hitting bullets (fragments) on the obstacle are not fully studied, and the applied models and methods do not fully take into account the design parameters of protective obstacles.

The purpose of the article is to investigate the process of interaction of a bullets with a protective obstacle in the form of a set of compatible cylinders.

The main material. The use of single cylinders and bonded structures are only two of the possible means of increasing the strength of protective structures [8]. Another possible way to increase the strength of protective structures is a method that consists not of a nozzle of structures in the hot state with tension, but by the formation between the component structures (cylinders) of the gap into which the liquid (gas) is injected under pressure. By placing the cylinders in each other and adjusting the pressure of the liquid (gas) in the free zones between the cylinders, it can be achieved that at the 
same thickness in the cylinder walls, the pressure in the inner cylinder can be greater than in a single cylinder [9].

For a single cylinder, the ultimate pressure in it can reach half the strength limit of the material. For bonded and compatible cylinders, the maximum pressure is twice as high as for a single cylinder. For compatible cylinders, the limit pressure can be increased by another $25 \%$. If autofretted cylinders are used for compatible cylinders, the limiting pressure in the inner cylinder can be four times higher than for a single cylinder [9].

The prop that occurs in compatible cylinders and in bonded cylinders is not the same thing. The prop in the bonded cylinders, brought to a certain limit, then remains constant for the entire period of operation of the bonded cylinders. Prop in compatible cylinders can be variable.

Consider a structure consisting of two cylinders - the outer (2) and inner

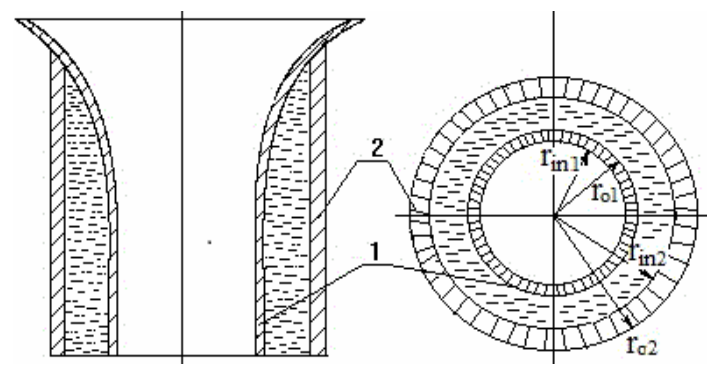

Fig. 1. Scheme of a compatible cylinder

(1), with the outer diameter of the inner cylinder, in contrast to the bonded cylinders, is smaller than the inner diameter of the outer cylinder. Fluid is injected under pressure into the gap between the outer and inner cylinders (Fig. 1).

Using the known formula for calculating normal stresses in the tangential direction $[9,10]$ :

$$
\sigma_{\theta}=\frac{p_{i n} \cdot r_{i n}^{2}-p_{e x} \cdot r_{o}^{2}}{r_{o}^{2}-r_{i n}^{2}}+\frac{\left(p_{i n}-p_{e x}\right) \cdot r_{o}^{2} \cdot r_{i n}^{2}}{r^{2} \cdot\left(r_{o}^{2}-r_{i n}^{2}\right)},
$$

where $p_{i n}-$ is the internal pressure in the cylinder, $\mathrm{Pa} ; p_{e x}-$ is external pressure on the cylinder, $\mathrm{Pa} ; r_{i n}-$ is the internal radius of the cylinder, $\mathrm{m} ; r_{o}-$ is the external radius of the cylinder, $\mathrm{m} ; r-$ is the current radius of the cylinder, $\mathrm{m}$.

For compatible cylinders, the following expressions can be written [9]: when $r=r_{\text {in }}$

$$
\sigma_{\theta}=p_{i n} \cdot \frac{1+k_{r}^{2} \cdot\left(1-k_{p}\right)}{k^{2}{ }_{r}-1},
$$

when $r=r_{\mathrm{o}}$

$$
\sigma_{\theta}=p_{i n} \cdot \frac{2-k_{p}^{2} \cdot\left(1+k_{r}^{2}\right)}{k_{r}^{2}{ }_{r}-1},
$$

where

$$
k_{r}=\frac{r_{o}}{r_{i n}}, k_{p}=\frac{p_{e x}}{p_{\text {in }}} .
$$

Pressure in the radial direction [9]: 
on the inner surface

$$
\sigma_{r}=p_{i n} \cdot \frac{2 \cdot k_{r}^{2} \cdot\left(1-k_{p}\right)}{k_{r}^{2}-1}
$$

on the outer surface

$$
\sigma_{r}=p_{i n} \cdot \frac{2 \cdot\left(1-k_{p}\right)}{k_{r}^{2}-1} .
$$

Equating the values of stresses to the allowable stress for the cylinder material $[\sigma]$, to determine the expression $\sigma_{\theta}$ when $r=r_{i n}$ we obtain the formula for determining the maximum allowable internal pressure [9]:

$$
p_{i}=[\sigma] \cdot \frac{k_{r}^{2}-1}{2 \cdot k_{r}^{2} \cdot\left(1-k_{p}\right)} .
$$

If the protective structure consists of two cylinders (outer and one inner), then for the outer cylinder:

$$
k_{p 2}=\frac{p_{e x 2}}{p_{\text {in } 2}}=0,
$$

the maximum allowable pressure will be:

$$
p_{\text {in } 2}=[\sigma] \cdot \frac{k_{r 2}^{2}-1}{2 \cdot k_{r 2}^{2}} .
$$

For any intermediate cylinder (if the protective structure consists of several cylinders: external and several (i) internal), the maximum allowable internal pressure can be written as:

$$
p_{\text {ini }}=\left[\sigma_{i}\right] \cdot \frac{k_{r i}^{2}-1}{2 \cdot k_{r i}^{2}\left(1-k_{p i}\right)} .
$$

Maximum allowable internal pressure in the inner cylinder with $n$ cylinders [9]:

$$
p_{i n}=[\sigma] \cdot \frac{k_{r n}^{2}-1}{2 \cdot k_{r n}^{2}}+\sum_{2}^{n-1}\left[\sigma_{i}\right] \cdot \frac{k_{r i}^{2}-1}{2 \cdot k_{r i}^{2}}+[\sigma] \cdot \frac{k_{r 1}^{2}-1}{2 \cdot k_{r 1}^{2}} .
$$

For a compatible design consisting of two cylinders, the value of the internal pressure in the outer cylinder is determined by the equation:

$$
p_{i 2}=[\sigma] \cdot \frac{k_{r 2}^{2}-1}{2 \cdot k_{r 2}^{2}} .
$$

The value of the internal pressure in the inner cylinder is determined by the equation:

$$
p_{i 1}=[\sigma] \cdot \frac{k_{r 1}^{2}-1}{2 \cdot k_{r 1}^{2}}+[\sigma] \cdot \frac{k_{r 2}^{2}-1}{2 \cdot k_{r 2}^{2}} .
$$

The contact pressure that occurs when passing a bullet in the middle of a cylinder of smaller diameter (than the diameter of the bullet) is determined by the expression [10]: 


$$
p_{c}=\frac{\delta \cdot E}{4 \cdot r_{b}^{3}} \cdot \frac{r_{b}^{2} \cdot\left(r_{c o}^{2}-r_{b}^{2}\right)}{r_{c o}^{2}},
$$

where $p_{c}$-the contact pressure between the bullet and the cylinder, $\mathrm{Pa} ; r_{c o}-$ outer radius of the cylinder, $\mathrm{m} ; r_{b}$ - radius of the bullet, $\mathrm{m} ; \delta$-tension between the bullet and the cylinder, m; $E$ - is the modulus of elasticity of the cylinder material, $\mathrm{Pa}$.

To determine the parameters of the process of interaction of the ball with a protective barrier in the form of compatible cylinders, we equate $p_{i}=p_{c}$.

Algorithm for solving the problem. Determine the depth of penetration of the bullet from the AK-74 into the protective barrier in the form of compatible cylinders. Output data: $r_{\text {bullet }}=0,00273 \mathrm{~m} ; r_{\text {icl }}=0,0025 \mathrm{~m} ; r_{\mathrm{ocl}}=0,0035 \mathrm{~m}$; $r_{\mathrm{ic} 2}=0,0036 \mathrm{~m} ; r_{\mathrm{oc} 2}=0,0057 \mathrm{~m} ; f=0,9 ; \quad E=2,1 \cdot 10^{5} \mathrm{M \Pi a} ; \quad l=0,012 \mathrm{~m}$; $[\sigma]=3 \cdot 10^{3} \mathrm{MPa}$ (Fig. 2).

The force under which the bullet will move along the inner surface of the cylinder, determine the formula based on the equation given in $[8,10]$ :

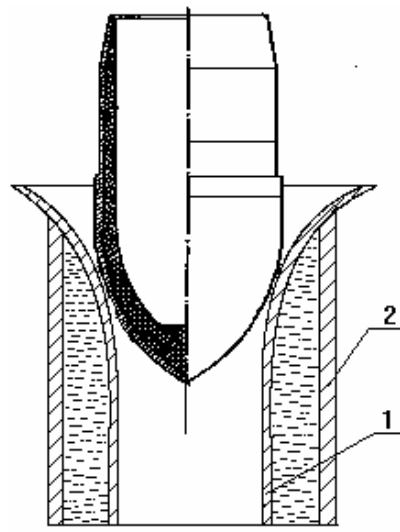

Fig. 2. The scheme of movement of a bullet along the compatible cylinder

$$
P=f_{1} \cdot p_{c} \cdot \pi \cdot D \cdot k \cdot l
$$

where $f_{1}$ - effective coefficient of friction between the bullet and the inner surface of the cylinder, $f_{1}=2 \cdot m \cdot f[11] ; m-$ the number of pairs of contact surfaces of the bullet with the inner surface of the cylinder; $p_{c}-$ contact pressure, $\mathrm{Pa} ; D$ - bullet caliber, $\mathrm{m}$; $l$ - length of the bullet, $\mathrm{m} ; k$ - the proportion of the bullet that entered in the cylinder, $0 \leq k \leq 1$.

The depth of penetration of the bullet into the cylinder $\mathrm{h}$ is determined by the formula:

$$
h=\frac{E_{\Sigma}}{P},
$$

where $P$ - the force under which the bullet moves along the inner surface of the cylinder, $H ; E_{\Sigma}$ - kinetic energy of a bullet, $J\left(E_{\Sigma}=2019 J\right)$.

Define value $k_{r}=\frac{r_{e x}}{r_{i n}}$ for outer 2 and inner 1 cylinders:

$$
k_{r 2}=\frac{r_{o 2}}{r_{i n 2}}=\frac{0,0057}{0,0036}=1,58 ; k_{r 1}=\frac{r_{01}}{r_{i n 1}}=\frac{0,0035}{0,0025}=1,4 .
$$

The value of the internal pressure in the outer cylinder is determined by the formula (12): 


$$
p_{i 2}=3 \cdot 10^{9} \cdot \frac{\left(1,58^{2}-1\right)}{2 \cdot 1,58^{2}}=0,9 \cdot 10^{9} \mathrm{~Pa} .
$$

The value of the internal pressure in the inner cylinder is determined by the formula (13):

$$
p_{i 1}=3 \cdot 10^{9} \cdot \frac{\left(1,4^{2}-1\right)}{2 \cdot 1,4^{2}}+3 \cdot 10^{9} \cdot \frac{\left(1,58^{2}-1\right)}{2 \cdot 1,58^{2}}=1,65 \cdot 10^{9} \mathrm{~Pa} .
$$

We equate the value of the internal pressure in the inner cylinder and the value of the contact pressure that occurs when the bullet passes in the middle of the inner cylinder:

$$
p_{i 1}=p_{c}
$$

and determine the magnitude of the force under which the bullet will move along the inner surface of the cylinder (14):

$$
P=f_{1} \cdot p_{c} \cdot \pi \cdot D \cdot k \cdot l=0,9 \cdot 1,65 \cdot 10^{9} \cdot 3,14 \cdot 0,00545 \cdot 0,012=305108 \mathrm{H} .
$$

The depth of penetration of the bullet into the cylinder $h$ is determined by the formula:

$$
h=\frac{2019}{305108}=0,0066 \mathrm{~m} .
$$

Thus, the obtained value of the depth of penetration of the bullet into the compatible cylinder is less than the depth of penetration of the bullet into the bonded cylinder, which is given in research [8].

\section{Conclusions}

1. The process of interaction of a bullet with a protective obstacle in the form of a set of hollow cylinders of compatible type is investigated.

2. A model for determining the depth of penetration of a high-velocity bullet into a hollow cylinder of a compatible type is proposed.

3. Calculations performed of the depth of penetration of the bullet from a Kalashnikov rifle (AK-74) into steel hollow cylinders of compatible type.

4. Further improvement of armor protection structures can be achieved by developing new technical solutions using the latest technologies.

\section{REFERENCES}

1. Petruchenko O.S. Obgruntuvannia parametriv bahatosharovoi zakhysnoi konstruktsii boiovykh mashyn na osnovi neliniinykh matematychnykh modelei. (Substantiation of parameters of multilayer protective construction of combat vehicles based on nonlinear mathematical models) - Manuscript. Dissertation for the degree of Doctor of Philosophy (Candidate of Technical Sciences) in the specialty 05.02.09 - Dynamics and Strength of Machines / O.C. Petruchenko - Lviv, 2018. - 160 p.

2. Lapitsky S.V. Metodologiya issledovaniya slozhnykh sistem voyennogo naznacheniya (Methodology for the study of complex military systems)/ S.V. Lapitsky, A.V. Kuchinsky, A.I. Sbitnev [and others]; ed .: S.V. Lapitsky. - K.: 2013. - 477 p.

3. Bruhl S.T. K voprosu modelirovaniya reaktsii korpusov legkobronirovannykh mashin na deystviye udarno- impul'snykh zagruzok (On the issue of modeling the reaction of lightly armored vehicle bodies to shock-pulse loading)// Bulletin of NTU "KPI". Coll. of sciences. wash. Series: New Solutions in Modern Technologies. - Kharkiv: NTU "KPI", 2013. - № 43 (1016). - P. 46-50. 
4. Vasilyev A.Yu. Chislennoye modelirovaniye reaktsii bronekorpusov legkobronirovanikh mashin na deystviye udarno-volnovoy zagruzki (Numerical simulation of the response of lightly armored vehicles to the effect of shock wave loading) // Mechanics and Mechanical Engineering. - KPI .: - Kharkiv, 2010. - №2. - P. 73-97.

5. Velichko L.D. Dynamika zakhysnoi konstruktsii pry udari kuli abo oskolka snariada (Dynamics of the protective structure when struck by a bullet or a projectile fragment) // Military Technical Collection / Academy of Land Forces. - № 13. - Lviv: ACB, 2015. - P. 13-19.

6. Gerasimov A.V. Teoreticheskiye i eksperimental'nyye issledovaniya vysokoskorostnogo vzaimodeystviya tel (Theoretical and experimental studies of high-speed interaction of bodies) / Ed. A.V. Gerasimova. - Tomsk: Publisher Tom. Univ., 2007 - 572 p.

7. Grigoryan V.A. Materialy i zashchitnyye struktury dlya lokal'nogo i individual'nogo bronirovaniya Materials and security structures for local and individual booking (Materials and protective structures for local and individual reservations) / VA Grigoryan, IF Kobylkin, V.M. Marinin, E.N. Chistyakov - M.: Izd. RadioSoft. 2008. - 406 p.

8. Kovtun A.V. Modeli vzaiemodii vysokoshvydkisnoho udarnyka z zakhysnymy pereshkodamy (Models of interaction of high-speed striker with protective obstacles) / A.V. Kovtun, V.O. Tabunenko, S.I. Nesterenko. // Strength of Materials and Theory of Structures / Strength of Materials and Theory of Structures. 2019. Issue 102,-P. 207-211.

9. Zayarny V.I. Osnovy teorii sovmeshchennykh sosudov (Fundamentals of the theory of combined vessels)/ V.I. Zayarny. - Lviv: Publishing House of the Lviv State. University, 1972. - $124 \mathrm{p}$.

10. Prakticheskiye raschety na prochnost' konstruktivnykh elementov. Ch. I. (Practical strength calculations of structural elements) / A. G. Dibir, O. V. Makarov, N. I. Pekelny, G. I. Yudin, M. N. Grebennikov. - Study. allowance. - Kharkov: Nat. aerospace. Universities «Kharkov aviation. Institute », 2007. - $102 \mathrm{p}$.

11. Kovtun A.V. Dinamika slozhnykh mekhanicheskikh sistem so svyazyami sukhogo treniya (Dynamics of Complex Mechanical Systems with Dry Friction Bonds). // Kovtun, V.F. Grekov, VA Procopius. - Kharkov: MO, 1996. - 116 p.

Стаття надійшла 12.05.2020

Ковтун А.В., Табуненко В.О., Нестеренко С.I.

\section{МОДЕЛЬ ВЗАЄМОДІЇ ВИСОКОШВИДКІСНОГО УДАРНИКА З ЗАХИСНОЮ ПЕРЕШКОДОЮ СУМІСНОГО ТИПУ}

В даній роботі розглянуто процес взаємодії кулі (осколку) з захисними перешкодами, які утворені набором пустотілих циліндрів сумісного типу. Запропоновані моделі визначення глибини проникнення ударника в перешкоду у вигляді набору пустотілих циліндрів сумісного типу. Наведені результати розрахунків величини глибини проникнення кулі в захисну перешкоду у вигляді набору сумісних циліндрів. Подальші дослідження пов'язані 3 вдосконаленням конструкцій бронезахисту шляхом розробки нових технічних рішень з використанням новітніх технологій.

Ключові слова: модель, високошвидкісний ударник, куля, захисна перешкода, деформация, порожнистий циліндр.

\section{Anatoly Kovtun, Volodimir Tabunenko, Sergey Nesterenko}

\section{MODEL OF HIGH-SPEED SHOCK INTERACTION WITH COMPATIBLE TYPE}

In connection with military operations, the issue of developing protection for military personnel against bullets and splinters remains an issue. Modern studies of the interaction of bullets and fragments with protective obstacles are based on the search for new types of structures and materials of protection. The focus is on the development of NATO-compliant protective structures to increase the level of protection for military personnel using low-cost, affordable materials with minimal production and intended use. 
Despite some advances in the study of solid-body impact, the known results of theoretical and experimental studies do not describe the overall picture of the interaction of the element of damage and interference. When designing protective structures, only certain aspects of the shock interaction are considered, based on the absorption of the kinetic energy of the element of damage. Therefore, it remains important for the scientific and technical task - to continue the study of the process of interaction of bullets (fragments) with protective obstacles, at the stages of penetration, penetration and their departure, which will allow to develop new models of protection structure of military personnel that are relevant for military use.

The main method of studying the process of striking and punching an obstacle with a bullet (fragment) is a combination of analytical and experimental studies. Analytical methods of research are based on mathematical modeling of stages of interaction of bullets (fragments) with elements of a protective obstacle with the subsequent carrying out of corresponding mathematical calculations. Experimental research methods are based on determining the level of security and require complex research in laboratory and polygonal conditions. The combination of analytical and experimental research results makes it possible to consider the level of security more fully.

In this work the process of interaction of a ball (fragment) with the protective obstacles formed by a set of hollow cylinders of compatible type is considered. Models for determining the depth of penetration of the impactor into the obstacle in the form of a set of hollow cylinders of compatible type are proposed. The results of calculations of the depth of penetration of the ball from Kalashnikov (AK-74) in steel hollow cylinders of compatible type are presented. Further research is concerned with improving the design of armor by developing new technical solutions using the latest technologies.

Keywords: model, high-speed impactor, ball, protective obstacle, deformation, hollow cylinder.

\section{УДК 531.66}

Ковтун А.В., Табуненко В.О., Нестеренко С.I. Модель взасмодії високошвидкісного ударника з захисною перешкодою сумісного типу // Опір матеріалів і теорія споруд: наук.-тех. збірник. - К.: КНУБА, 2020. - Вип. 105. - С. 64-72.

В даній роботі розглянуто прочес взаємодії кулі (осколку) з захисними перешкодами, які утворені набором пустотілих ииліндрів сумісного типу. Запропоновані моделі визначення глибини проникнення ударника в перешкоду у вигляді набору пустотілих ииліндрів сумісного типу. Наведені результати розрахунків величини глибини проникнення кулі в захисну перешкоду у вигляді набору сумісних ичліндрів. Подальщі дослідження пов'язані 3 вдосконаленням конструкцій бронезахисту шляхом розробки нових технічних рішень 3 використанням новітніх технологій.

Ил. 2. Бібліогр. 11 назв.

\section{UDC 531.66}

Kovtun A.V., Tabunenko V.A., Nesterenko S.I. Model of high-speed shock interaction with compatible type // Strength of Materials and Theory of Structures: Scientific-and-technical collected articles - Kyiv: KNUBA, 2020. - Issue 100. - P. 64-72.

In this work the process of interaction of a ball (fragment) with the protective obstacles formed by a set of hollow cylinders of compatible type is considered. Models for determining the depth of penetration of the impactor into the obstacle in the form of a set of hollow cylinders of compatible type are proposed. The results of calculations of the depth of penetration of the ball into the protective obstacle in the form of a set of compatible cylinders are presented. Further research is concerned with improving the design of armor by developing new technical solutions using the latest technologies.

Fig. 2. Ref. 11. 
УДК 531.66

Ковтун А.В., Табуненко В.А., Нестеренко С.И. Модель взаимодействия высокоскоростного ударника с защитной преградой совместного типа // Сопротивление материалов и теория сооружений. - К.: КНУБА, 2020. - Вып. 105. - С. 64-72.

В данной работе рассмотрен процесс взаимодействия пули (осколка) с зашитными препятствиями, которые образованы набором пустотельх иилиндров совместного типа. Предложены модели определения глубины проникновения ударника в препятствие в виде набора пустотельх иилиндров совместного типа. Приведены результаты расчетов величины глубины проникновения пули в защитную преграду в виде набора совместимых цилиндров. Дальнейшие исследования связаны с совершенствованием конструкций бронезащиты путем разработки новых технических решений с использованием новейших технологий.

Ил. 2. Библиогр. 11 назв.

Автор (науковий ступінь, вчене звання, посада): кандидат технічних наук, доцент, доцент кафедри бойового та логістичного забезпечення Національної академії Начіональної гвардії Украӥни КОВТУН Анатолій Васильович.

Адреса робоча: 61001 Україна, м. Харків, майдан Захисників Украӥни 3, НАНГУ, кафедра бойового та логістичного забезпечення, Ковтун А.В.

Мобільний тел.: +38(097) 708-04-41;

E-mail: kav-60@ukr.net

ORCID ID: http://orcid.org/0000-0002-8427-1005

Автор (науковий ступінь, вчене звання, посада): кандидат технічних наук, доцент, професор кафедри електротехнічних систем комплексів озброєння військової техніки Харківського національного університету Повітряних Сил ім. Івана Кожедуба, ТАБУНЕНКО Володимир Олександрович.

Адреса робоча: 61023 Україна, м. Харків, вулиия Сумська 77/79, ХНУПС, кафедра електротехнічних систем комплексів озброєння військової техніки, Табуненко В.О.

Мобільний тел.: +38(097) 225-62-60;

E-mail: tabunenko55@ukr.net

ORCID ID: http://orcid.org/0000-0003-1347-5390

Автор (науковий ступінь, вчене звання, посада): кандидат технічних наук, доиент, доцент кафедри автомобілів та транспортної інфраструктури Національного аерокосмічного університету ім. М.Є. Жуковского "Харківський авіаційний інститут», НЕСТЕРЕНКО Сергій Іванович.

Адреса робоча: 61070 Украӥна, м. Харків, вул. Чкалова, 17, НАУ «ХАI», дочент кафедри автомобілів та транспортної інфраструктури Національного аерокосмічного університету ім. М.Є. Жуковского «Харківський авіаційний інститут», НЕСТЕРЕНКО С.І.

Мобільний тел.: +38(096) 965-59-33;

E-mail: nesterenko.geo@gmail.com

ORCID ID: http://orcid.org/0000-0003-3119-9887 